\title{
THE USE OF INFORMATION AND COMMUNICATION TECHNOLOGY (ICT) FOR ACQUIRING ENGLISH
}

\author{
Hendra Eka Putra \\ Program Studi Tadris Bahasa Inggris Sekolah Tinggi Agama Islam Negeri Batusangkar \\ Korespondensi: Jorong Balai Batu Lima Kaum Batusangkar \\ e-mail: hendra_kadam@yahoo.com
}

\begin{abstract}
Information and communication technology is the study, development and application of computer-based information systems using telephones, televisions, radios, mobiles, computers and computer software to convert, store, process, protect and transmit information. This article focuses on the use of Information and Communication Technology (ICT) which can give valuable information and chance for language learners to acquire English language in real life.
\end{abstract}

Kata kunci: Information and Communication Technology, acquiring English

\section{INTRODUCTION}

$\mathrm{I}$ ndonesia government has done several efforts to increase the quality of English teaching in Indonesia in order that Indonesian students' competence in using English will be improved both in written or in spoken. Unfortunately, the result as expected has not been achieved yet. The students' mastery of English is not satisfactory. This problem may happen because of several factors such as teachers, students, teaching and learning facilities, curriculum, and others. Teachers might not be successful in teaching because they failed to find an appropriate teaching media to teach students. It may also happen because the students do not know to select an appropriate for them to use. Other possible may cause these problems. It can be said that they may contribute to the successful of acquiring language, especially English. Fortunately, the development of technology may give chance to students (language learners) to learn with or without teachers to overcome their learning problems. Then, by using Information and Communication Tech-nology teachers may guide students in learning inside or outside the classroom.

Therefore, an appropriate medium must be apllied in developing students' English skills. It will be possible if teachers or lecturers train their students to use $I C T$ such as computer, video, and some other media to motivate students to have high self confidence to speak in English.

\section{WHAT IS INFORMATION AND COMMUNICATION TECHNOLOGY (ICT)}

Information and Communication Technology (ICT) refers to technologies that provide access to information through telecommunication (Wikipedia, 2013: 1). It includes the Internet, wireless networks, cell phones, and other communication media. In the past few decades, information and communication technologies have provided society with a vast array of new communication 
capabilities. For example, people can communicate with others in different countries using technologies such as instant messaging, voice over IP (VoIP), and video-conferencing. Social networking websites like Facebook allow users from all over the world to remain in contact and communicate on a regular basis. Modern information and communication technologies have created a "global village," in which users of it can communicate with others across the world as if they were living next door. For this reason, ICT is often studied in the context of how modern communication technologies affect society.

According to Wikipedia (2013: 2), Information and communication technology (ICT), is often used as an extended synonym for Information Technology (IT), but is a more specific term that stresses the role of Unified Communication and the integration of telecommunication (telephone lines and wireless signals), computers as well as necessary enterprise software, middleware, storage, and audio-visual systems, which enable users to access, store, transmit, and manipulate information. The term ICT is now also used to refer to the convergence of audio-visual and telephone network with computer networks through a single cabling or link system. There are large economic incentives (huge cost savings due to elimination of the telephone network) to merge the audio-visual, building management and telephone network with the computer network system using a single unified system of cabling, signal distribution and management.

While, Whitmar (2012: 1) states that Information and Communication Technology nowadays usually means computer-based management of data or ideas. In a broader sense, communication and information technologies are the foothold on which humankind distinguished itself from other animals. The difference between today's information and communications technologies and humankind's first simple shared concepts hints at what these technologies now mean for our world. Therefore, the explosion of information and technologies exposes a wealth of new opportunities to explore knowledge of language.

Then, Bumpres (2013: 1) states that $I C T$ is the acronym for Information Communications Technology. ICT Communication focuses on the storage, retrieval, manipulation, transmission or receipt of digital data. ICT devices are ever-evolving and individuals, businesses and organizations actively look for ways to use the different types of ICT to access, receive and send information.

\section{TYPES OF INFORMATION AND COMMUNICATION TECHNOLOGY (ICT)}

According to Bumpres (2013: 2), there are several types of Information and Communication Technology. It includes Electronic Mail, Facsimile, Video conferencing, and Telephone conferencing.

Bumpress (2013: 2) states that Electronic Mail, or email, can be used to transmit and receive digital information. Email is the most common form of electronic communication. Emails are ideal because attachments such as files and pictures can be sent along with the email. In order to use this type of ICT, users must have an email account. There are many email providers that allow individuals to create an account at no charge. Businesses and organizations usually have an inside provider they use to setup email accounts for their employees, clients and other personnel.

Facsimile - fax for short - was more common before electronic mail 
came along. Faxes that are still viable for many information transactions and at times, are often the preferred method of communication for businesses and organizations. A fax is sent over a telephone network. Information that is sent over a telephone network travels through the phone line and is picked up by the receiving fax machine. Fax machines can also be digital, meaning the transmission may be sent over a wireless connection and picked up by the recipient's fax machine.

Video conferencing is ideal for business communication when different persons may need to be reached across the country or across different time zones. Video conferencing uses a camera, microphone monitor, loudspeakers and an Internet connection. This equipment allows users to see, listen and speak with one another; users can also communicate without leaving home offices.

Telephone conferencing allows readers to plug one party into another party. Organizations and businesses utilize telephone conferences when they have audio portions for participants to listen to. Phone conferences function as listen-only sessions or allow listeners to participate. Participants are connected into a telephone conference by being phoned; they also have the option of calling into the conference with a code or special number to bridge the call. At times, telephone and video conferencing may be combined when cameras and microphones are not available.

In addition, Dephoff (2012: 1) states that communication through technology can be done through applying several communication media. They include Digital Networks, Packet Switch Network, Personal Digital Assistant, and E-learning.

Modern telephone systems use digital networks that don't rely on physical line connectivity between two callers. Instead, they use fiber optics to carry and transmit the digital connection, and can handle thousands of calls simultaneously. Along with this development, the Asymmetric Digital Subscriber Line (ADSL) network was established. ADSL provides faster Internet connectivity, and allows use of the phone and Internet at the same time.

The latest development in communication is a cheaper and faster network using packet switching. This is called Voice Over Internet Protocol (VOIP). Instead of cable or fiber optics, it uses "packets," or small bits of data transmitted on the Internet. Around the same time, Wireless Fidelity, or WiFi, networks were established. WiFi describes an Internet connection setup that allows handheld users to connect quickly using radio signals, and to move comfortably without using any cable wires. Wireless Application Protocol, likewise, is a current technology that enables access for handheld devices programmed with advance networking hardware and software.

A personal digital assistant is a handheld computer device designed for users who need small but flexible electronic utilities. It is often called a "personal diary" because it allows fast organization and manipulation of information for a reasonably limited storage size.

Electronic learning is an educational system that can be accessed anywhere via the Internet. This development contributes to better communication because it teaches us to adapt and utilize the latest technologies. We have learned to reach out and interact by using online tools such as software phones, instant messaging and blogging.

Based on the experts' opinion above, it can be summarized that there are eight types of Information and Communication Technology. They are 
Electronic Mail, Facsimile, Video Conferencing, Telephone Conferencing, Digital Networks, Packet Switch Network, Personal Digital Assistant, and E-learning.

ICT AND ITS USE FOR ACQUIRING ENGLISH

There are many uses of
Information and Communication Technology for acquiring English. Koptyug (2013: 1) states that using information and computer technology in language classroom can be an overcome to several problems in language teaching; the memory problem, preparation for ICT vocabulary work, autonomous ICT vocabulary work (the great motivator) and uses of ICT in language teaching.

To solve the problem in the memory problem, teachers may start any new topic with a large or small number of new words, which students are supposed to learn, to be able to understand the theme and to talk or/and write about it themselves. They also knows that it is next to impossible to make students learn all the necessary words. In real situation, students may learn the vocabulary items, but they will be easy to forget them. Therefore, to activate the new vocabulary, to recycle the words and expressions, teacher needs some new techniques which will be suitable and satisfying for the new generation which is living in the era of $I C T$, or maybe even post-ICT.

Moreover, Koptyug (2013: 1) also states that there are some uses of ICT in language teaching. Those uses are as follows:

1. The regular lesson

It is possible to hold a regular lesson in a computer class with internet access. Here, teachers may download the necessary material beforehand, and have students work through it, helping out when needed. There are many sites that provide learning materials on the internet.

2. Using the net as a research resource

Users may decide to search the web for some data. Every user (possibly students) gets an address, or a name, or some words, which they find through a search engine. They may take notes while working, so that next day, they can have feedback. Such lessons are extremely motivational, since students enjoy using the Web, and they have an additional motivation because they know that they have to report to their peers during the next lesson.

3. Web site projects

Users are engaged in a project which is related to one of our topics. Students, especially, may write their essays in class. Then, teachers check them. After checking students' essays, they may have a lesson in the computer lab where they type their works and email them to a project site, or post them if possible.

4. Real communication

In this global era, it is possible for students from different contry to email a letter to their imaginary friend in another country and tell them about their country. Through this information and communication technology, they have real virtual friends, to use a funny modern word combination, with whom they exchange information, photos etc.

At last, Elia in McDougald (2009: 19) states that ICT plays apart in fostering intercultural competence which is a a part of learning a second of foreign language. It means that $I C T$ provides a variety of different approaches as well as 
styles that reinforce the material delivered in other formats. It is also supported by Jarvis in McDougald (2009: 19) who states that by integrating basic IT skills in the EFL classroom, teachers may develop language skills and equip students with technology skills.

Based on the theories above, it can be said that ICT is very useful for language learners in enriching their knowledge and skills of English. By using ICT, language learners may look for learning material and some other sources with or witouth teachers beside them. Therefore, through ICT language learners can progress their knowledge and skills of English individually.

\section{HOW TO USE ICT IN CLASSROOM}

According to Lanni (2005), there are some skills and strategies involved in ICT based language activities. They are as follows:

1. Technology skills in the use of hardware and software

2. Navigation skills (search, discrimination, skimming, scanning, evaluation of source, material, types of texts, style, information, etc)

3. Choice of suitable paths inside the hypertext/ hypermedia in order to find desired result

4. Definition of the characteristics of the information (origin, quality, relevance, and reliability)

5. Use of search engines (planning the search, devising the possible key words, choosing different types of search engines according to the purpose of search)

6. Use of the information according the pre-determined objectives and tasks

7. Use of the written language as a means of communication (formal/ informal) in email and chat exchange as well as blogs

8. Use the oral language as a means of communication in video conferencing

9. Use of the oral language as a means of communication while discussing, reporting, negotiating and mediating inside the class with teacher and other students.

Then, Pimentel (1999) proses several steps in using ICT through communication tools, assessment, and Content Exchange and Group Work. These three steps can be seen clearly in the following part.

Communication tools can be done through assignment, discussion boards (forums), Live chat, content delivery (lesson), and journal. First, Assignments will allow teachers to specify a task that requires students to prepare digital content (any format) and submit it by uploading it to the server. Typical assignments include essays, projects, reports and so on. This module includes grading facilities. Next, Discussion Boards (Forums) can be structured in different ways, and can include peer rating of each posting. The postings can be viewed in a variety for formats, and can include attachments. By subscribing to a forum, participants will receive copies of each new posting in their email. A teachers can impose subscription on everyone if they want to.

Then, Live Chat module allows participants to have a real-time synchronous discussion via the web. This is a useful way to get a different understanding of each other and the topic being discussed - the mode of using a chat room is quite different from the asynchronous forums. The Chat module contains a number of features for managing and reviewing chat discussions. Fourth, Content Delivery (Lesson) delivers content in an interesting and flexible way. It consists 
of a number of pages. Each page normally ends with a question and a number of possible answers. Depending on the student's choice of answer they either progress to the next page or are taken back to a previous page. Navigation through the lesson can be straight forward or complex, depending largely on the structure of the material being presented. At last, through Journal teachers may ask students to reflect on a particular topic, and students can edit and refine their answer over time. This answer is private and canonly be seen by teachers who can offer feedback and a grade on each journal entry.

Assessment can be done through Quizzes and workshop. Quizzes may allow teachers to design and set quiz tests, consisting of multiple choice, truefalse and short answer questions. These questions are kept in a categorized database, and can be re-used within courses and even between courses. This modul can also allow multiple attempts. Each attempt is automatically marked, and teachers can choose whether to give feedback or to show correct answers. This module includes grading facilities. While, Workshop is a peer assessment activity with a huge array of options. It allows participants to assess each other's projects, as well as exemplar projects, in a number of ways. It also coordinates the collection and distribution of these assessments in a variety of ways.

Content Exchange \& Group Work can be done through Database, Glossary and Wiki. First, Database module may allow teachers or lecturers and/or students to build, display and search a bank of record entries about a topic. The format and structure of these entries can include images, files, URLs, numbers and text among other things. Then, Glossary activity may allow participants to create and maintain a list of terms and definitions. It can be used to build an annotated list of useful websites or FAQs. At last, Wiki may enable documents to be authored collectively. A history of all contributions and changes is stored, and the wiki can be rolled back to a previous version at any time.

\section{CONCLUSION AND SUGGESTION}

1. Conclusion

Related to previous part, it is clear that the development of information and communication technology may give a big chance for language learners to enhance their knowledge and skills of English. By considering the use of ICT, teachers in classroom may attract their students to apply it in order to enrich their vocabulary, even to increase their knowledge of English language.

\section{Suggestion}

Since developing technology has big influence on the human's life, the goverment has to consider to put all these kinds of work within the framework of the school curriculum, so that the students may learn many more new words, they also acquire inter-cultural and interactive skills. Needless to say, among those who benefit from all the new activities combined with all the traditional ones, it can be listed, last but not least, teachers. 


\section{BIBLIOGRAPHY}

Bumpres, Bianca. 2013. Types of ICT Communication. http://www.ehow.com/info_81575 62_types-ict-communication.html. Retrieved on January 6, 2013.

Dephoff, Jacklyn. 2012. The Use of Information Communication Technology. http://www.ehow. com/info_the use-ict-communication.html. Retrieved on Sepetember 12, 2012.

Koptyug, Nina M. Novosibirsk. 2013. ICT, Vocabulary and Motivation. http://www.teachingenglish.org.uk /articles/ict-vocabulary-motivation. Retrieved on March 7th, 2003.

Lanni, Daniela. 2005. The Rationale: ICT in Language Teaching in 6 Points. http://www. Itiscannizzaro. net/lanni/articles/rationale.htm. Retrieved on January 29th, 2013.

McDougald, Jermaine. 2009. The Use of Information and Communication Technology (ICT) in the EFL Classroom as A Tool to Promote L2 (English) among Non-Native Pre-Service English Teachers.
(Unpublished Thesis). Leon: The University of Leon Press.

Michael. 2012. Advantages and Disadvantages of ICT Communication. http://www.ict. comt.net/englossary.htm.

Retrieved on November 17, 2012.

Pimentel, J.R. 1999. Design of NetLearning Systems based on Experiental Learning. Journal of Asynchronous Learning Networks 3 (2), 64-90. Retrieved on Jaunary 29th, 2013 from http://www.aln. org/publications/jaln/v3n2_piment el.asp.

Whitmar, Abe. Information and Communication Technologies. http://www.techterms.com/definiti on/ict. Retrieved on Januari 4, 2013.

Wikipedia. 2013. Information and Communication Technologies. http://en.wikipedia.org/wiki/Infor mation_and_communication_techn ologies. Retrieved on December 7, 2012. 